\section{Okul Öncesi Çağındaki Üstün Yetenekli Çocuklar: Neredeyiz? Nereye Gitmeliyiz?}

\author{
Preschool Age Gifted/Talented Children: \\ Where Are We? Where Should We Go?
}

Turkish Journal of Special Education

Research and Practice

2021, Volume 3 Number 1, p 94-112 https://dergipark.org.tr/trsped

DOI: 10.37233/TRSPED.2021.0114

Article History:

Received 3 January 2021

Revised 20 June 2021

Accepted 23 June 2021

Available online 15 December 2021

\author{
Asiye Parlak-Rakap (101
}

\begin{abstract}
Öz
Türkiye'de üstün/ özel yetenekli okul öncesi dönem çocuklarıyla ilgili ilk çalışmalar 1988 yılında başlamıştır. Son beş yılda yapılan ulusal alanyazında yayımlanmış çalışmaların tarandığı bir çalışmanın, hem 11. Kalkınma Planı hem de Birleşmiş Milletler Kalkınma Programı 2030 Sürdürülebilir Hedeflerine ulaşmada izlenebilecek bir yol gösterebileceği düşünülmektedir. Bu bağlamda, çalışmanın amacı ülkemizde 2016-2020 yılları arasında okul öncesi dönem üstün yetenekli çocuklara yönelik yapılmış çalışmaları, araştırma türü, araştırma grubu ve araştırmanın yürütüldüğü yere dayalı olarak analiz etmektir. Alanyazın taraması șeklinde planlanan bu çalışmada 2016-2020 yılları arasında yapılmıș, Ulakbim aracılığıyla ulaşılan makaleler ile Ulusal Tez Merkezi tarafından erişimi sağlanan yüksek lisans/ doktora tezlerinden konuyla ilgili olan çalışmalar "üstün yetenek" ve "okul öncesi" anahtar kelimeleriyle taranmıştır. Veriler, içerik analizi yöntemiyle analiz edilmiștir. Bulgular, geliștirilen iki ana kategori ve bu kategorilerle ilişkili alt kategoriler ve kodlar altında incelenmiştir. Elde edilen verilere göre, çalışmaların çoğunluğu makaledir; çalışmalarda ağırlıkla nicel araştırma deseni kullanılmıştır; çalışmaların katılımcıları/çalışma grubu çoğunlukla öğretmenlerdir ve çalışmalar yüksek oranda üç büyükşehirde gerçekleştirilmiştir. Alanyazın taramasının sonuçlarının bazıları daha önce yapılan çalışmalarla uyumluluk arz etmektedir. Tespit edilen farklılıklar açıklanmaya çalışılmıştır.
\end{abstract}

Anahtar Sözcükler: Üstün yetenekli çocuklar, okul öncesi dönem, Türkiye’de yapılmış çalışmalar.

\begin{abstract}
First studies about gifted/talented preschool children in Turkey started in 1988. Reviewing studies published in national literature in last five years would have a meaningful effect in reaching both the 11th Development Plan and the 2030 Sustainable Goals of the United Nations Development Program. In this context, the aim of this study was to analyze studies conducted for gifted/talented preschool children between 2016-2020 in Turkey based on sub-categories, namely research type, research group and the place where research was conducted. This study, which was planned as a literature review, reviewed studies published between 2016 and 2020. The articles were accessed through Ulakbim and master's / doctoral theses related were accessed by the Turkish National Thesis Center. Turkish keywords "üstün yetenek (giftedness/talented)" and "okul öncesi (preschool)" were scanned through publications. The data were analyzed by content analysis method. Findings were analyzed under two main categories, sub-categories and codes associated with these categories. According to the data obtained, most of the publications were articles; quantitative research design was used predominantly in these studies; the participants / working groups were mostly teachers; and the studies were mostly conducted in three metropolitan cities. Some of the results of this literature review are consistent with previous studies. The detected differences were tried to be explained.
\end{abstract}

Keywords: Gifted children, preschool period, studies in Turkey

Önerilen Atıf Şekli (Suggested Citation): Parlak-Rakap, A. (2021). Okul öncesi çağındaki üstün yetenekli çocuklar: Neredeyiz? Nereye gitmeliyiz? Turkish Journal of Special Education Research and Practice, 3 (1), 94-112 https://doi.org/10.37233/TRSPED.2021.0114 


\section{Giriş}

Erken çocukluk dönemi kavramı uluslararası bağlamda 0-8 yaşı kapsamaktadır. Türkiye'de bu kavram 0-6 yaş arasındaki çocuklara vurgu yapılan okul öncesi dönem yerine kullanılmaktadır (Gürkan, 2009; Kağıtçıbaşı, 2012). Okul öncesi dönem, Piaget'e göre mantıksal çıkarımların henüz görülmeye başlanmadığı işlem öncesi döneme karşılık gelmektedir. Çocukların sırasıyla somut ve soyut mantık yürütme dönemleri olan somut işlemler dönemi ve soyut işlemler döneminden önce gelmekte ve bu dönemlerin temelini oluşturmaktadır. Bu nedenle, yaşamın ilk yıllarını oluşturan bu dönem bilişsel gelişimde önemli bir dönemdir (Ormrod, 2012). Yapılan güncel çalışmalar sşığında ortaya çıkan bu sürecin önemli olmasının nedenlerinden bir diğeri, çocukların çocukluklarında yaşadıkları deneyimlerin, onların gelecek yaşamlarında belirleyici izlerinin olmasıdır. $\mathrm{Bu}$ izler bazen alışkanlıkların temeliyken bazen bireyin sosyal, duygusal ve akademik yaşamına yön vermektedir. Beyin üzerinde yapılan araştırmalar, önceki inanışın aksine, erken çocukluk dönemindeki yaşantı ve ilişkilerin gelecek yaşamı belirleyici rolünü gözler önüne sermiștir (Bethell vd., 2019; Shonkoff ve Phillips, 2000). Fiziksel, sosyal, duygusal ve kültürel çevredeki yaşantılar ve özellikle yetişkinlerle kurulan ilişkiler, çocukların öz farkındalık, öz düzenleme, öz disiplin, öz güven gibi alanlarda duygusal gelişimlerini etkilemektedir (Bear vd. 2017; Diamond, 2012; Duckworth ve Gross, 2014; Eisenberg vd., 2009; Mischel, 2014).

Fark edilmesi gereken önemli noktalardan biri, her çocuğun birbirinden ayrı bir birey olduğu, o nedenle de farklı gereksinimleri olduğu, farklı gereksinimlerin bazı durumlarda özelleşebileceğidir (Woodhead, 2005). Bu gereksinimler bazen öğrenmede yaşanan özel güçlükler ya da işitme ya da konuşmada yaşanan sorunlarken bazen üstün yeteneğe sahip olmaktır. Üstün yetenekli bireyler, zekâlarını normal olarak tanımlanan sınırlar dışındafarklı şekilde kullanabilmektedir. Üstün yetenekli çocukların gereksinimleri, sahip oldukları özelliklerle ele alınmalı, bu özel gereksinime uygun düzenlemeler yapılmalı ve bu düzenlemeler, yukarıda da vurgulandığı gibi yaşamın kalıcı izler bırakan okul öncesi döneminde başlamalıdır (Ataman, 2003; Diken vd., 2016).

Üstün yeteneklilik kavramı tarihsel süreç boyunca çeşitli şekillerde ele alınmıştır. Başlangıçta Sir Francis Galton'un zekâ üzerine yapmış olduğu çalışmalarla üstün zekâ olarak tanımlanırken, Piaget, Vygotksy, Dabrowski ve Gardner gibi bilim insanlarının zekâya getirdikleri kapsamlı bakış açısıyla birlikte özel ya da üstün yetenek kavramı kullanılmaya başlamıştır (Ataman, 2003; Dağlığlu, 2014). Günümüzde ise üstün zekâ (gifted) ve üstün/özel yeteneğin (talented) birbiri yerine kullanılan kavramlar olduğu; hatta zaman zaman bir arada kullanılmasının tercih edildiği göze çarpmaktadır (Heller, 2004). Oysa her ikisi de farklı anlamlara ve farklı paradigmalara sahiptir. Gagne'ye (2013) göre üstün zekâ, olağanüstü doğal yeteneklere sahip olma olarak tanımlanmakta, bireyi akranlarının ilk \%10'u arasına yerleștiren bu doğal yetenekleri kullanabilmeye vurgu yapmaktadır. Diğer deyişle, doğuştan sahip olunan özel doğal yeteneklerdir. Üstün yetenek ise, doğuştan getirilen yeteneklerin sistematik şekilde geliştirilerek yetkinliklere (bilgi ve beceriler) dönüşmesini, bireyin sahip olduğu yetenekte, belirli bir alanda ustalaşmak için aktif kılınmasını esas almakta, akranları arasında ilk \%10'a yerleștirmektedir. Üstün zekânın, henüz belirli bir yetenek alanında ustalaşma gerektirmeyen erken çocukluk yıllarında fark edildiğinde, eğitim ortamlarında verilecek sistematik eğitim ve destekle üstün yeteneğe dönüștüğü söylenebilir (Gagne, 2013; Heller, 2004).

Günümüzde üstün yeteneklilik kavramı gelişimin bütün boyutlarıyla ele alınmakta, başlangıçtaki gibi sadece zekâ gibi doğuştan gelen genetik faktörlere bağlanmamakta, genetik faktörlerin çevreyle etkileşimine önem verilmektedir. Böylece üstün yeteneklilik, 
genetik faktörlerin yanında bilișsel ve duyuşsal gelişim, eğitim ve çevresel şartların yer aldığı bir uyum sürecine atıfta bulunmaktadır. Bu nedenle, üstün yetenekli çocuklar düşünüldüğünde sadece zekâ değil çocuğun çok yönlü gelișimi esas olmakta; evde, okulda ve çocuğun sosyal ve kültürel çevresinde kurduğu ilişkiler, öncü ve belirleyici bir role evrilmektedir (Majid ve Alias, 2010).

Gerek beyin araştırmaları gerekse erken çocukluk çalışmalarının vurguladığı önemli nokta, erken yaşlardan itibaren sağlanan desteğin hayata güçlü bir başlangıçta etkili olduğudur. Bu destek, aileler, öğretmenler, okul öncesi eğitim kurumları, eğitim politikaları, vb. pek çok çalışmayla sağlanmalıdır. Bu çalışmalara Türkiye'de 20. yüzyılın ikinci yarısında başlanmıştır ve günümüze kadar farklı yelpazede pek çok çalışmaya rastlanmaktadır. Bu çalışmaların 2016 yılına kadar hangi alanlarda ve nasıl yürütüldügünü görmek açısından Yılmaz (2018) tarafından yapılan alanyazın taraması sonuçları önemlidir. Erken yaşlardan itibaren üstün yetenekli çocukların ülkemizde nasıl tanılandığı ve onlara nasıl imkânlar sağlandığı konusunda yapılan bu alanyazın taraması sonuçlarından biri, ilk çalışmaların 1988 yılında başladığı yönündedir. 2016 yılına kadar yayınlanan yüksek lisans-doktora çalışmaları ve makalelerin incelendiği çalışmada öne çıkan sonuçlar: yapılan yayınların çoğunlukla üstün yetenekli çocukların okul öncesi dönemde tanılanmasını sağlayabilecek belirleme ve değerlendirme ölçeği geliștirilmesi araştırmaları ve betimsel araştırmalar olduğu yönündedir. Yazar, okul öncesi eğitimin 2016 yılında yürürlüğe giren Bilim ve Sanat Merkezleri (BİLSEM) Yönergesinde yer almasının yapılacak çalışmaları artıracağını vurgulamaktadır. Söz konusu yönergede, Madde 5'e "okul öncesi eğitim" kavramının eklenmiş olduğu belirtilmektedir (Özel Eğitim ve Rehberlik Hizmetleri Genel Müdürlüğü, 2016). 2016 yılında atılan bu adımın, okul öncesi dönem üstün yeteneklilik çalışmalarında önemli gelişmelere yol açması beklenmektedir. Bu tarihten beş yıl sonrasında, hangi çalışmalarla nasıl gelişmeler kaydedildiği, gelecek beş yıl ve sonrası için bir planlama yapılmasında önemli olacaktır.

Yılmaz (2018) tarafından alanyazına kazandırılan çalışma, 2016 yılına kadar okul öncesi dönem üstün yetenekliler alanında yapılmış çalışmaları aydınlatmıştır. 2016 yılında güncellenen Bilim ve Sanat Merkezleri Yönergesi'nde ise okul öncesi döneme vurgu yapılmıştır. 2016 yılından sonra nasıl çalışmalar yapıldığının anlaşılması geleceğe dönük çalışma ve politikalara ışık tutacaktır. Güncel alanyazın gözden geçirildiğinde 2016 yılı sonrasında yapılmış farklı derleme çalışmalarına da rastlanmaktadır. Ulaşılan bu çalışmalardan biri üstün yeteneklilerin eğitimi politikalarının değerlendirilmesi üzerine yapılan derlemedir (Çitil, 2018) ve genel anlamda politikaları ele almıştır. İkincisi, okul öncesi dönem üstün yetenekli çocukların eğitimine dikkat çeken bir çalışmadır (Bapoğlu vd., 2016) ve öneriler getirmekte, var olan durumu incelemektedir. Üçüncüsü ise, erken çocukluk dönemindeki üstün yetenekli çocuklarla ilgili yapılmış yüksek lisans çalışmalarının incelendiği sistematik bir alanyazın taramasıdır (Koç ve Saranlı, 2017). Her biri alana katkı sağlayan bu çalışmalara ek olarak, 2016 yılı başından 2020 yılı sonuna kadarki beş yılı kapsayan ve okul öncesi dönem üstün yetenekli çocuklarla ilgili yapılan çalışmaların kapsamlı olarak ortaya konulması, nerede olduğumuzu görme ve gelecek çalışmaları planlamada önemli rol oynayacaktır. Bu çalışmanın, ülkemizin de üyesi olduğu Birleşmiş Milletler Kalkınma Programı'nın (United Nations Development Programme) 2030 hedeflerinden olan nitelikli eğitim (hedef 4) ve eşitsizliklerin azaltılması (hedef 10) amaçlarının gerçekleştirilmesinde önemli etkisi olacağı düşünülmektedir. Bu bağlamda, bu çalışmanın amacı, ülkemizde 2016-2020 yılları arasında okul öncesi dönem üstün yetenekli çocuklara yönelik yapılmış çalışmaları, araştırma türü, araştırma grubu ve araștırmanın yürütüldüğü yere dayalı olarak analiz etmektir. 


\section{Yöntem}

\section{Evren ve Örneklem}

Çalışmanın örneklemini 2016-2020 yılları arasında yapılmış, Ulakbim aracılığıyla ulaşılan makaleler ile Ulusal Tez Merkezi tarafından erişimi sağlanan yüksek lisans/ doktora tezlerinden konuyla ilgili olan çalışmalar oluşturmaktadır. Yapılan alanyazın taraması sonucunda, üç yüksek lisans ve bir doktora tezine ve 20 makaleye ulaşılmıştır. Çalışmanın örneklemini dört tez ve 20 makale oluşturmaktadır. Örneklem belirlenirken kullanılan ölçütler; çalışmanın Ocak 2016- Aralık 2020 yılları arasında belirtilen veri tabanlarında yayımlanmış olması; makalelerin anahtar kelimelerinin "üstün yetenek" ve "okul öncesi" olması; tezlerin tamamında "üstün yetenek" ve "okul öncesi" kavramlarının yer almasıdır. Bu çalışma, okul öncesi dönem üstün yetenekli çocuklarla ilgili ülkemizde yürütülmüş ve yayınlanmış olan ve araştırmacının ulaşabildiği makale ve tez çalışmalarıyla sınırlıdır. Özel yetenek kavramı anahtar kelime olarak taranmamıştır.

\section{Veri Toplama Yöntemi}

Çalışmada, var olan bir durumu ortaya koymayı amaçlamaktadır. Bu nedenle, bir nitel araştırma yöntemi olan doküman incelemesi kullanılmıştır. Doküman incelemesi, basılı ya da elektronik belgelerin içeriğinin sistemli bir şekilde analiz edilmesini, elde edilen bulguların değerlendirilmesi ve yorumlanmasını, böylece konuyla ilgili anlayış geliştirmeyi kapsamaktadır (Kıral, 2020). Bu alanyazında kullanılacak dokümanlar, makale ve tez çalışmalarıdır. Bu dokümanlarla ilgili ölçütler belirlenmiş ve çalışmalar bu ölçütler ışığında belirlenmiştir. Ulusal Tez Merkezi aracılığıyla ilgili tezlere, Ulakbim aracılığıyla da alanda yapılan makale çalışmalarına ulaşılmıştır. Kullanılan anahtar kelimeler, üstün yetenek ve okul öncesidir. Alanyazın taramasında her iki kelimenin de bir arada kullanılması temel alınmıştır. Araştırma, araştırmacının ulaştığı dokümanlarla sinırlidır.

\section{Veri Analizi}

Verilerin analizinde içerik analizi kullanılmıştır. İçerik analizi, haberler, görseller, günlükler, vb. dokümanların nesnel şekilde incelenerek aktarılması ve nicel olarak ifade edilmesidir (Elo ve Kynga"s, 2007). Betimsel içerik analizi çalışmaları, belirli bir çalışma alanındaki güncel durumun yansıtılmasını ve genel bakış açısının okuyucu ve araştırmacıların gözleri önüne serilmesini sağlamaktadır (Çalık ve Sözbilir, 2014).

Belirlenen anahtar kelimelerle Türkçe kaynaklar tarandıktan sonra ulaşılan makaleler tek tek incelenmiş ve kendi aralarında ortak kategoriler oluşturulmuştur. Daha önceden bu çalışmanın amacıyla benzer yapılmış olan alanyazın taraması çalışmaları gözden geçirilerek içerik analiziyle elde edilen kategoriler yeniden değerlendirilmiştir.

Alanyazın taramasıyla elde edilen çalışmalar makale ve yüksek lisans/doktora tezi olarak iki ayrı kategoride ele alınmıştır. Bu kategoriler, kullanılan araştırma yöntemleri (nicel araștırma deseni, nitel araştırma deseni, karma desen, alanyazın taraması kodlarıyla), araştırma grupları (çocuklarla yapılan araștırmalar, öğretmenlerle yapılan araştırmalar, öğretmen adaylarıyla yapılan araştırmalar kodlarıyla) ve araştırmanın yapıldı̆̆g yer olmak üzere üç farklı alt kategoride incelenmiştir. Veri analizinde geçerlik güvenirlik çalışması için, okul öncesi eğitim alanında lisans derecesine sahip ve öğretmen olarak çalışan bir uzmanla kodlayıcı uyumuna bakılmıștır. Uzmana çalıșmanın amacından bahsedilmiş, geliştirilen kategoriler açıklanmış ve çalışma hakkında bilgi verilmiştir. 25 çalışmanın analiz edildiği araștırmada kodlanan toplam 63 maddenin üçünde anlaşmazlık 
görülmüştür. Üç anlaşmazlık, alanda uzman bir araştırmacının görüşüyle çözülmüştür. Buna bağlı olarak, bir makale inceleme dışı bırakılmış, 20 makale ile dört tez değerlendirilmiştir. Kodlayıcılar arası görüș birliği, \%95,2 olarak belirlenmiştir.

\section{Bulgular}

Veriler iki kategoride analiz edilmiştir. Bu kategoriler: Makale çalışmaları ve yüksek lisans/doktora tezi çalışmalarıdır. Hem makaleler hem de yüksek lisans/doktora çalışmaları, kullanılan araştırma yöntemleri, araştırma grupları ve araştırmanın yapıldığı yer alt kategorilerinde incelenmiștir.

2016-2020 yılları arasında yapılan makaleler incelendiğinde 20 makaleden üçünün (\%15) alanyazın taraması, kalan $17 \operatorname{sinin}$ (\%85) ise araştırma makalesi olduğu bulunmuştur. Alanyazın taraması çalışmalarından ikisinin yaratıcılık ve üstün yetenek kavramlarına odaklandığı, birinin ise üstün yetenekli okul öncesi çağı çocuklarıyla ilgili yapılmış tezleri incelediği bulunmuştur. Yaratıcılık ve üstün yetenekli okul öncesi çağı çocuklarıyla ilgili sadece alanyazın taramasına rastlanması, bu konuda yapılmış herhangi bir araştırma yayınına rastlanmaması göze çarpmaktadır.

Araştırma makalelerin çoğunluğunu nicel araştırma deseni (\%40) ve \%40'ını nitel araştırma deseni oluşturmaktadır. Buna ek olarak sadece bir tanesi (\%5) karma desen kullanılarak yapılmıştır. Üçü ise (\%15) alanyazın taramasıdır (Şekil 1).

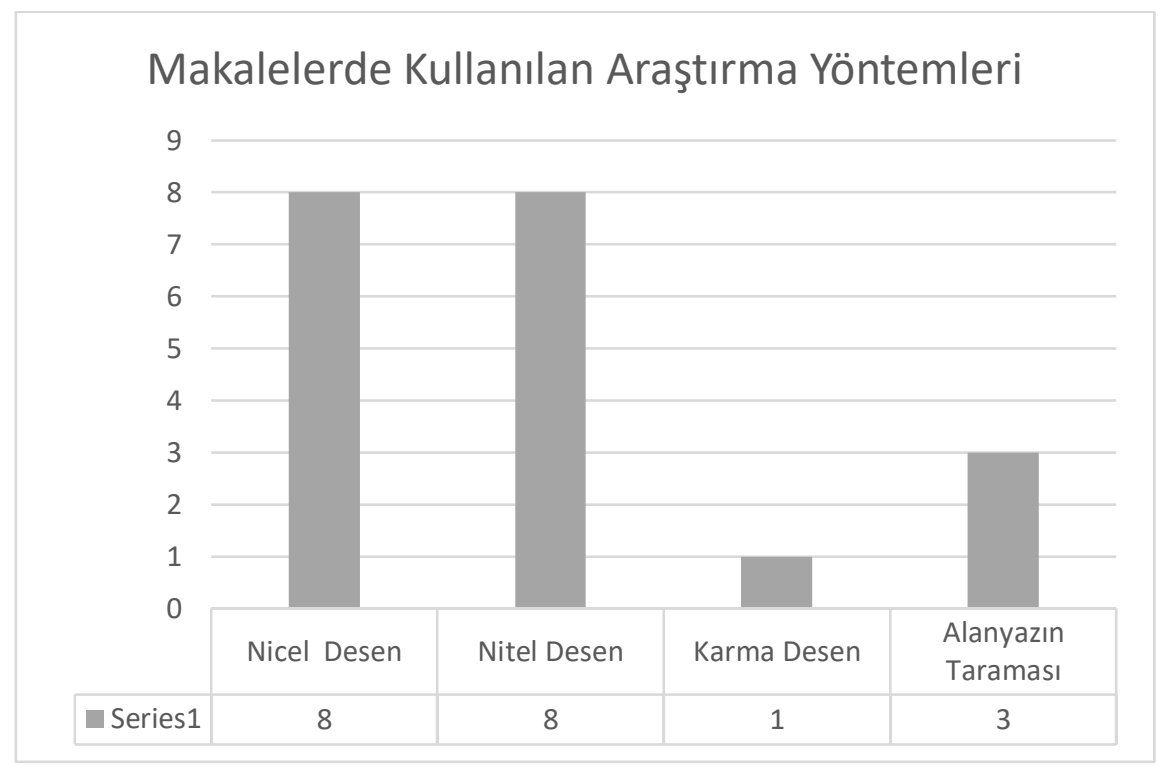

Şekil 1. 2016-2020 yılları arasında makalelerde kullanılan araştırma yöntemleri dağılımı

Belirtilen tarihler arasında okul öncesi üstün yetenekli çocuklarla ilgili yapılan tez çalışmaları incelendiğinde ise dört tez çalışmasından üçünün (\%75) yüksek lisans ve birinin (\%25) doktora çalışması olduğu; Şekil 2'de görüldügü üzere, doktora tez çalışması dahil üçünün (\%75) nicel araştırma deseni, sadece birinin (\%25) nitel desen kullandığı; karma desenin kullanıldığı herhangi bir çalışmaya ise rastlanmadığı tespit edilmiştir.

Belirtilen tarihler arasında yayınlanan makalelerin araștırma grubuna göre yapılan incelemesinde, Şekil 2'deki bulgular ortaya çıkmıștır. İnceleme sonuçlarına göre, toplam 17 araştırma makalesinin beşi çocuklarla (\%24), sekizi öğretmenlerle (\%47) ve dördü öğretmen adaylarıyla (\%24) yapılmıștır. Aileler, okul idareleri ya da kanun yapıcılar gibi okul öncesi dönemde üstün yetenekli çocukların eğitimlerinde etkisi olan yetişkinlerle yapılmış bir çalışmaya rastlanmamıştır. Öğretmenlerle yapılmış sekiz makale 
çalışmasından altısı nitel, kalan ikisi ise nicel araştırma deseniyle planlanmışken, öğretmen adaylarıyla uygulanmış çalışmaların üçü nicel, biri de nitel deseni kullanmıştır. Çocuklarla yapılan beş çalışmadan üçü nicel, biri nitel ve biri karma desenle yapılmıştır. Çocuklarla yürütülmüş nicel çalışmalardan sadece biri deneyseldir. Okul öncesi dönem üstün yetenekli çocuklarla uygulanmak üzere yapılan ölçek geliştirme çalışmalardan biri çocuklarla, biri de öğretmenlerle yürütülmüştür. Ayrıca yapılmış nicel çalışmalardan birinin de okul öncesi dönem üstün yeteneklilerde dil gelişimine odaklandığı görülmüştür. Öğretmenlerle yapılan çalışmalar incelendiğinde, özellikle nitel çalışmaların, öğretmenlerin üstün yetenekli çocuğun tanılanması, kabulü, vb. gibi öğretmenlerin çocuğa yaklaşımına odaklandığı görülürken, yine nitel araştırmalardan birinin öğretmenlerin üstün yetenekli okul öncesi çağı çocuğu için BEP hazırlamasına odaklandığı ortaya çıkmıştır.

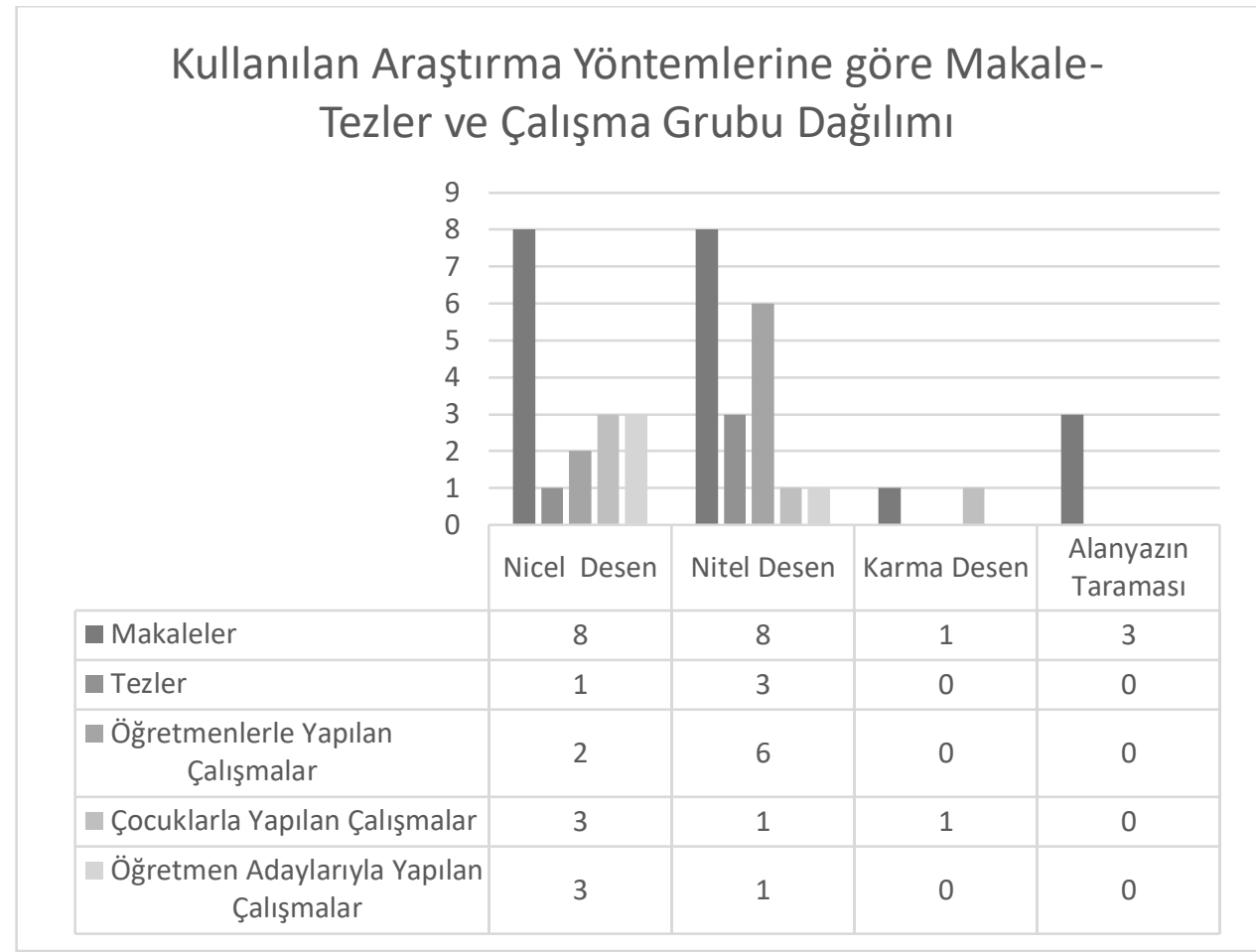

Şekil 2. 2016-2020 yılları arasındaki çalışmalarda araştırma grubuna, çalışma türüne ve araştırma desenine göre dağılımı

İnceleme, tezler bağlamında yapıldığında ise, sadece bir doktora tezi sürecinde çocuklarla çalışıldığı, diğer üç yüksek lisans tezinde ise öğretmenlerle çalışıldığı görülmüştür (bknz. Şekil 2). Tezlerde, öğretmen adayları, aileler, okul idarecileri ya da kanun yapıcı gibi çocukların yaşamındaki etkin bireylerle çalışma planlanmadığı bulunmuştur. Çocuklarla yürütülen nicel doktora tezi çalışmasında, önce ölçek geliştirme çalışması yapıldığı ve ardından, geliştirilen ölçek kullanılarak üstün yetenekli okul öncesi dönem çocuklarının belirlendiği ve deneysel bir çalışma uygulandığı saptanmıştır. 2016 yılında okul öncesi öğretmenleriyle yapılan nicel çalışmanın (Daştan, 2016) bulgularına göre, öğretmenin sahip olduğu öz yeterlik inancı ile üstün yeteneklilere yönelik genel tutum arasında pozitif bir ilişki vardır. 2018 yılında öğretmenlerle yapılan nicel yüksek lisans bulguları ise bir önceki çalışmaya yeni bir boyut kazandırır niteliktedir (Sarar, 2018). Önceki çalışmayla uyumlu olan bulgu, öğretmenlerin öz yeterlilik düzeyleri ile üstün yetenekli çocuklara yönelik algı düzeyleri arasındaki pozitif ilişkidir. Ancak bilgi düzeylerine göre incelendiğinde, öğretmenin üstün yetenekliler eğitimine ilişkin öz 
yeterlik ve algı düzeyleri ile üstün yetenekli okul öncesi çocuğuna ilişkin bilgi düzeyi arasında negatif bir ilişki söz konusudur. Diğer deyişle, bilgi düzeyi azaldıkça öz yeterlik ve algı düzeyi artmaktadır. Öğretmenlerle yapılan nitel araştırmada ise BİLSEM öğretmenleri, BİLSEM'e giden çocuklar ve aileleriyle görüşmeler yapılmıştır (Gökdemir, 2017). Görüşme sonuçları, BİLSEM öğretmenlerinin okul öncesi dönemde yapılacak tanılama ve sağlanacak eğitim hizmetlerinin önemine vurgu yaptıklarını göstermiștir.

Makale çalışmaları, çalışmanın yapıldığı yere göre incelendiğinde çocukların katıldığı yer belirtilmiş bütün çalışmaların üç büyükșehirden birinde gerçekleştiği görülmektedir. Öğretmenlerle yapılan çalışmalardan birine ilişkin yer bilgisine ulaşılamamış; birinin üç büyükșehirden birinde yapıldığı ve bir çalışmanın uluslararası boyutta katılımcısının olduğu bulunmuştur. Diğer beş çalışmadan biri Doğu Anadolu bölgesinde yapılmışken biri de KKTC'de yürütülmüş olup, diğerleri İç Anadolu ve Ege bölgelerinde uygulanmıştır. Öğretmen adaylarıyla yapılan dört çalışmadan ikisinde yürütüldükleri yere ilişkin açık bir bilgiye ulaşılamazken bir çalışmanın üç büyükşehirden birinde ve diğer çalışmanın da Doğu Anadolu'da bir ilde gerçekleştirildiği görülmüştür.

Tez çalışmaları da yapıldığı yere göre incelendiğinde, ikisinin ülkemizin üç büyük şehrinden birinde, birinin İç Anadolu'da bir büyükşehirde ve diğer kalanının ise ülke çapında uygulandığı tespit edilmiştir. Makaleler ve tez çalışmaları toplu olarak incelendiğinde ise aşağıdaki tablo ortaya çıkmaktadır (Tablo 1).

Tablo 1. 2016-2020 tarihleri arası üstün yetenekli okul öncesi çocuklarla ilgili yapılan makale ve tezlerin genel analiz sonuçları

\begin{tabular}{lcc}
\hline Değişken & Makaleler & Tez çalıșmaları \\
\hline Coocuklarla yapılan çalışmalar & 5 & 1 \\
Öğretmenlerle yapılan çalışmalar & 8 & 3 \\
Öğretmen adaylarıyla yapılan çalışmalar & 4 & 0 \\
Nitel araştırma deseni & 8 & 1 \\
Nicel araștırma deseni & 8 & 3 \\
Karma desen & 1 & 0 \\
Alanyazın taraması & 3 & 0 \\
Üç büyükşehirden birinde & 5 & 2 \\
Diğer illerde & 7 & 2 \\
Uluslararası & 2 & 0 \\
\hline
\end{tabular}

Bulgular değerlendirildiğinde, okul öncesi dönem üstün yetenekli çocuklarla ilgili 2016-2020 yılları arasında yapılan araştırma temelli çalışmaların toplamda 21 olduğu ve bu çalışmaların dördünün yüksek lisans/doktora tez çalışması, kalanlarının ise makale çalışmaları olduğu görülmüştür.

\section{Sonuç}

21 çalışmanın 6'sının çalışma grubu/ katılımcıları çocuklar, 11'i öğretmenler ve sadece makalelerle sınırlı olmak üzere dördü de öğretmen adaylarıdır. Bu bulguların gösterdiği önemli noktalardan ilki son beş yılda, Türkiye'de yayımlanan tezler ve makalelerde devlet koruması altındaki çocuklarla, ailelerle, idarecilerle ya da diğer paydaşlarla yapılmış bir çalışmaya rastlanmamasıdır. Oysa ailenin üstün yetenekli çocuğa yaklaşımının eğitim ve ev ortamının düzenlenişi açısından önemli olması, idarecilerin mevcut ortamı yasal çerçevede düzenleme yetkisinin olması, devlet koruması altındaki üstün yetenekli çocukların fark edilmesi ve gerekli düzenlemelerin yapılmasının gerekliliği gibi konular ülkemizin 11. Kalkınma Planı’nda (Çocuk Çalışma Grubu Raporu, 2018) vurgulanmaktadır. Ayrıca, 2019-2023 kalkınma hedeflerinde de altı çizilmektedir. 
Aile, çeşitli raporlar, çalışmalar ya da geleceğe yönelik hedeflerde etkisinin ve öneminin vurgulandığı önemli bir kurumdur. Giriște verilen tanımda da belirtildiği gibi üstün/özel yetenek, çocuğun gelişim sürecinde erken dönemlerde fark edilmeye başlar. Bu fark ediş, üstün/özel yetenekli çocuğun normal gelişim gösteren akranlarına kıyasla bazı gelişimsel basamaklarda önde olmasıyla görülebilir. Üstün/özel yeteneğin fark edilmesinde ilk ve önemli rol, bebekliğinden itibaren bakımıyla ve büyümesiyle birinci derecede ilgilenen kişilere aittir ki bu kişiler çoğunlukla aile bireyleri olmaktadır. Üstün/özel yeteneğin fark edilmesi ve belirlenmesinden sonra, üstün yetenekliler eğitiminde de aile yine pivot role sahiptir (Gallagher, 2008; Yörük, 2020). Aile yapılarının, aile tutumlarının, ailelerin sosyoekonomik ve sosyokültürel altyapılarının üstün/özel yetenekli çocukların fark edilmesi, tanılanması, ortamın düzenlenmesi ve eğitim fırsatlarının sağlanmasında bu derecede önemli olması (Gallagher, 2008) sebebiyle ailelerle yapılan çalışmalara daha sık rastlanması gerektiği düşünülmektedir.

Ailenin çocuğun bakımını üstlenemediği durumlarda çocuk devlet korumasına alınmaktadır. Devlet koruması, çocuğun yaşına göre farklı modellerle sağlanmaktadır. Suğur ve Doğru (2010) tarafından yapılan çalışmada, yetiştirme yurdunda kalan çocuklar devleti kendilerine ailelerinden daha yakın görmekte, devletin güçlü, adil ve gereksinimlerini karşılayan otorite olduğunu belirtmektedirler. Devlet koruması altındaki üstün yetenekli çocukların tespit edilmesinin ve onların gereksinimlerinin karşılanmasının gerekliliği karşımıza çıkmaktadır. Bu çalışma grubuyla yapılmış bir çalışmaya ise alanyazın taramasında rastlanmamıştır.

Okul idarecileri ya da diğer paydaşlarla yapılacak çalışmalar, var olan yönetmelik ve yönergelerin uygulamaya dönük sonuçlarını ortaya koyması açısından önemlidir. Çitil (2018)'in belirttiği üzere, yasa, yönetmelik ya da yönergeler açısından güçlü bir zemini olan düzenlemelerin üstün yetenekli çocukların lehine nasıl uygulamalara firsat oluşturduğunun anlaşılması, yeni düzenlemeler için gereklidir. Örneğin, Bapoğlu vd. (2016) çalışmalarında, üstün yetenekli çocukların eğitiminde bir zenginleştirme çalışması olarak görülen BİLSEM'lerin, yönetmeliğinde okul öncesi ifadesi geçmesine rağmen bu dönem çocuklarına yönelik bir çalışmalarının olmadığını vurgulamaktadırlar. Aynı şekilde, yazarlar çocuk üniversitelerinin zenginleştirme boyutuna değinmektedirler. Ancak taranan alanyazında bununla ilgili bir çalışmaya rastlanmamıştır. Yine aynı çalışmada üstün yetenekli çocukların eğitiminde kullanılan diğer iki yaklaşımın, hızlandırma ve gruplamanın, Türkiye'de nasıl uygulandığına dair bir bilgiye rastlanmadığı görülmekte, bu durum bu alanyazın taramasında da görülmektedir.

Veri analizi sonucunda ortaya çıkan diğer bir bulgu, çocuklarla yapılmış çalışmaların altısından dördünün nicel araştırma deseni, birinin nitel ve birinin de karma desene uygun şekilde uygulandığıdır. Bu çalışmaların ise, çoğunlukla üstün yetenekli çocuğu tanılamada kullanılabilecek ölçek geliştirme çalışması oldukları görülmüştür. Koç ve Saranlı (2017) bu alanda yapılmış yüksek lisans-doktora çalışmalarını inceledikleri çalışmalarında nicel ve karma desen kullanılan çalışmaların yoğunlukta olduğunu, bu çalışma bulgularıyla benzer şekilde nitel desenin uygulandığı çalışmaların az olduğunu aktarmışlardır. Ayrıca nicel çalışmaların, çoğunlukla ölçek geliștirme veya uyarlama çalışmaları olduğunu belirtmektedirler. Koç ve Saranlı'nın bulgularıyla doğru orantılı olarak bu çalışmada da nicel araștırmaların bir araya getirilerek analiz edildiği herhangi bir meta-analiz ya da nitel araștırmaların bir araya getirilerek incelendiği bir meta-sentez çalışmasına rastlanmamıştır. Yazarların vurguladığı gibi, bunun nedeni her iki analiz için yeterli sayıda araştırmanın olmaması olabilir.

2016-2020 arasındaki çalışmaların analiz edildiği bu çalışmanın bulgularına göre; bir çalışma üstün yeteneklilerde görülen eş zamanlı olmayan gelişimi incelemiş (Saranlı, 
2017), bir çalışma dil gelişimine odaklanmış (Saranlı vd., 2017), bir çalışmada sayı algısındaki farkındalıkları belirlenmeye çalışılmış (Özdemir, 2019), bir çalışmada problem çözme becerisinin uygulanan programın etkililiğine dayalı olarak gelişimi test edilmiş (Bildiren ve Kargın, 2019), bir çalışmada nöropsikolojik yaklaşım temelli geliştirilen ölçek aktarılmış (Karateke, 2019) ve 2016 tarihli doktora çalışmasında (Karateke, 2016) bu ölçek kullanılarak üstün yetenekli çocukların sosyal beceri gelişimleri deneysel bir uygulama sonrasında test edilmiştir. Çalışmalarda eş zamanlı olmayan gelişim, dil gelişimi, sosyal gelişim, nöropsikolojik gelişim, bilişsel gelişim gibi gelişimin farklı alanlarına odaklanıldığı görülse de çocuğun birey olarak katılımcı olduğu bir çalışmaya rastlanmamıştır. Bu durumun çeşitli sebepleri olabilir. Bunlardan bazıları yaş grubu özellikleri, bazıları araştırmacıların çocuklarla çalışma yapma konusunda deneyimlerinin olmaması, bazıları ailelerden çalışma izninin alınmasındaki zorluklar, bazıları bu dönemde tanılama hizmetlerinin sınırlı olması, vb. olabilir. Oysaki kapsayıcı ve bütünleştirici eğitimin önemli bir unsuru olarak görülen bireysel farklılıklara saygı ve bireysel farklılıklara uyumlu sınıf ortamı gibi konuların, çocuklarla yapılacak çalışmalarla pekiștirilip zenginleșeceği düșünülmektedir.

Üstün yetenekli okul öncesi dönem çocuklarına ilişkin öğretmenlerle yapılmış çalışmaların çoğunlukla nitel araştırma yöntemiyle uygulandığı (11 çalışmadan 7'si), kalan dördünün ise ikisi yüksek lisans çalışması olmak üzere nicel desene uygun yürütüldüğü görülmüştür. Nitel araştırma deseniyle yapılan makalelerde, okul öncesi öğretmenlerinin üstün yetenekli çocuklara ilişkin bilgi düzeyleri ve görüşleri (Bildiren vd., 2020; Karadağ ve Yıldız Demirtaş, 2017; Yoleri vd., 2018), uluslararası platformda kapsayıcı okul öncesi eğitim ortamlarında öğretmen uygulamaları (Dağlığlu vd., 2017), özel yetenekli çocukların belirlenmesine yönelik görüşleri (Bildiren vd., 2020; Mindivanlı Akdoğan vd., 2017) ve üstün yetenekli çocuklara ilişkin metaforik algıları (Orhan Karsak ve Gider, 2019) araştırılmıştır. Nicel araştırmalarda ise okul öncesi dönem üstün yetenekli çocuklara ilişkin algı ve eğitim ihtiyaçlarının belirlenmesi; öz-yeterlik, tutum, algı ve bilgi düzeyi arasındaki ilişki ile okul öncesi dönem üstün yetenekli çocukları tanılama aracı geliştirilmesinin amaçlandığı görülmüştür. Okul öncesi öğretmenlerinin öz yeterlik düzeyinin üstün yeteneklilere yönelik tutumlarını olumlu etkilediğine ilișkin veri sunan bir çalışma (Daştan, 2016) olduğu gibi, öz yeterlilik düzeyleri arttıkça algı düzeylerinin de arttığı, bilgi düzeyleri arttıkça öz yeterlilik düzeyleri ve algı düzeylerinin aynı şekilde arttığını vurgulayan (Sarar, 2018) bir çalışmaya da rastlanmıştır. Bu çalışmalar, okul öncesi öğretmenlerinin üstün yetenekli çocuklara ilişkin bilgi düzeylerindeki ve öz-yeterliklerindeki artışın olumlu etkilerini vurgulamakta, bu konuda sağlanacak hizmet içi eğitimleri önermektedir. Benzer öneriler, Çitil'in (2018) çalışmasında da karşımıza çıkmaktadır. Çitil, bunlara ek olarak, hizmet içi eğitim verecek personelin, bu alanda yeterli donanıma sahip bireyler olması gerektiğine değinmektedir. $\mathrm{Bu}$ çalışmalarla benzer şekilde, Yazıcı vd. (2017), çalışmalarında öğretmenlere verilen hizmet içi eğitimin önemi vurgularken benzer bir eğitimin hizmet öncesinde okul öncesi öğretmen adaylarına da verilmesi gerekliliğini belirtmişlerdir.

Öğretmen adaylarıyla yapılan çalışmalar incelendiğinde ise makale çalışmalarıyla sınırlı kaldığı görülmektedir. Okul öncesi eğitim, sınıf eğitimi ve PDR öğretmenliği anabilim dallarında öğrenim görmekte olan son sınıf öğretmen adaylarının üstün yeteneklilere ilişkin tutumlarını araştırdığı çalışmasında Ata vd. (2020) PDR öğretmen adayları kadar yüksek olmamakla birlikte olumlu bir tutuma sahip olduklarını bulmuştur. Bir diğer çalışma (Metin vd., 2017), çoğunluğunu okul öncesi öğretmen adaylarının oluşturduğu $(\% 29,4)$, Türkçe Öğretmenliği, Sınıf Öğretmenliği, Sosyal Bilgiler Öğretmenliği ve Bilgisayar ve Öğretim Teknolojileri Öğretmenliği eğitimi alan öğretmen 
adaylarının da katıldığı bir araştırmadır. Okul öncesi öğretmen adaylarının "Üstün Yeteneklilerin İhtiyaçları ve Destek" alt boyutunda diğer gruplara oranla yüksek olumlu tutuma sahip oldukları bulunmuş hem Özel Eğitim dersi hem de Öğretmenlik Uygulaması dersleriyle artan bilgi düzeyinin tutumu da olumlu etkilediği sonucuna ulaşılmıştır. Bunun aksine, Akar (2019) 11 farklı disiplinden öğretmen adayının hizmet öncesi aldıkları tek bir Özel Eğitim dersinin üstün yetenekli çocukları tanımada yeterli olmadığını ve üstün yetenekli çocuğu aday göstermede nesnel davranamadıklarını bulmuştur. Bu çalışmalar, bilgi düzeyinin sadece teorik değil aynı zamanda uygulamaya dönük derslerle desteklenmesi gerektiği önerisini getirmiștir. Duran ve Dağlıoğlu'nun (2017) okul öncesi öğretmen adaylarıyla yaptıkları metafor çalışması da bu bulguyu desteklemektedir. Yeterli bilgi sahibi olmadıklarında, sadece okul öncesi dönem üstün yetenekli çocukların olumlu özelliklerine odaklanmaktadırlar. Buna rağmen, kendi üzerlerindeki sorumlukları fark ettikleri görülmektedir.

Yapılan 21 çalışmadan yedisinin Türkiye'deki üç büyükşehirden birinde, kalan çalışmalardan sekizinin diğer illerde ve ikisinin uluslararası bağlamda uygulandığı görülmekte; çocuklarla yapılan bütün çalışmaların ise üç büyükşehirle sınırlı kaldığına rastlanmaktadır. Bu bulgu, Koç ve Saranlı'nın (2017) ülkemizde bu konuya ilişkin yapılan yüksek lisans-doktora çalışmalarını inceledikleri alanyazın taraması bulgularıyla uyumludur. Bu durum, 2016-2020 tarihleri arasında da çalışmaların ülke genelinde yaygınlaşmadığını gözler önüne sermektedir.

Ülkemizde, üstün yetenekli çocukların eğitiminde destek mekanizması işlevi olarak görülen BİLSEM'lerde, özellikle okul öncesi döneme odaklanılmış bir çalışmaya rastlanmamıştır. Sadece bir çalışmada (Gökdemir, 2017) Türkiye genelinde BÍLSEM’lerde görev yapan öğretmenler, bu merkezlere devam eden öğrenciler ve aileleri yer almıştır. Bu çalışma her ne kadar üstün yetenekli çocuğun tanılanması sürecine genel bir bakışı ele alsa da okul öncesi dönemin öğretmenler tarafından vurgulandığı görülmektedir. Ülkemizde, Milli Eğitim Bakan Yardımcısı Mahmut Özer'in 16 Ekim 2020'de bir gazeteye verdiği röportajda belirttiği şekliyle, 81 ilde 182 BİLSEM faaliyet göstermektedir (Millî Eğitim Bakanlığı [MEB], 2020). BİLSEM sayılarının yüksek olması zenginleştirme çalışmaları bağlamında sevindirici bir durumken bu kurumlarda okul öncesi dönem üstün yetenekli çocuklara yönelik yapılmış bir çalışmaya rastlanmamıştır.

Okul öncesi dönem üstün yeteneklilere yönelik araştırma yayınlarının yanı sıra üç de alanyazın taramasına rastlanmıştır. Bunlardan ikisi yaratıcılık ve üstün yeteneklilik bağlamındayken (Bıçakçı ve Baloğlu, 2018; Yuvacı ve Dağlığlu, 2016), biri okul öncesi üstün yetenekli çocuklara ilişkin yapılmış yüksek lisans-doktora tez çalışmalarını (Koç ve Saranlı, 2017) incelemeye yöneliktir. Bilgilendirme ve geleceğe yönelik hedef belirlemede etkisi olduğu düşünülmektedir.

Sonuç olarak, ülkemizde son beş yılda okul öncesi dönem üstün yeteneklilerle ilgili yapılmış çalışmalar analiz edildiğinde ortaya çıkan ilk bulgu çalışmaların çoğunlukla makale olduğudur. Yüksek lisans/doktora çalışmalarına sınırlı sayıda rastlanmıştır. Bunun nedenleri, üstün yeteneklilere yönelik yüksek lisans/doktora programlarının ve/veya bu alanda çalışan uzman sayısının sınırlı olması olabilir.

İkinci bulgu, incelenen çalışmaların çoğunlukla nicel araştırma desenine uygun şekilde planlanmış olmasıdır. Nicel araştırma deseninden deneysel yönteme ise sadece bir çalışmada rastlanmıştır. Çalışmaların nitel araştırma desenine de önemli oranda yer verdiği görülmektedir. Oysa karma desenle yapılmış sınırlı çalışmaya ulaşılmıştır. Bu durumun çeşitli nedenleri olabilir. Bunlardan biri, geliştirilen araştırma sorularının benzerlik göstermesi olabilir. Araştırma sorularının, alanyazının etkili şekilde tarandıktan ve var olan durum incelendikten sonra geliştirildiği düşünülürse farklı 
kaynaklara ulaşmanın önemli olduğu görülmektedir. Nitel ya da karma araştırma desenleri de nicel desenler gibi güçlü ve güçlendirici çalışmalardır. Nitel araştırmalar var olan bir durumun yansıtılmasında etkilidir. Bu araştırma deseninin çeşitli yöntemleriyle deneyimlere ulaşılabilir, sosyolojik ve kültürel yapı göz önüne serilebilir, farklı durumlar ortaya çıkarılabilir, güncel ve geleceğe dönük teoriler geliştirilebilir ya da değişim yaşanabilir. Karma desen ise ilgili araştırma sorusu ya da sorularını açıklamada etkili yöntemler sunmaktadır. Diğer deyişle, benzer araştırma sorularının yönlendirdiği bilimsel araştırmalar yerine araştırma sorularının çeşitlenmesi ve farklı açılardan ele alınması bu alanın öneminin anlaşılmasında ve gelecekteki çalışmalara yön verilmesinde etkili olacaktır.

Üçüncü bulgu, okul öncesi dönem üstün yetenekli çocukların alanyazında sınırlı şekilde görünür olduğunu ortaya çıkarmaktadır. Çalışmaların çoğunlukla öğretmenlerle yapıldığı görülmektedir. Bunun temel sebebi, öğretmenlerin sınıf iklimi oluşturmada ve çocuğa rol model ve rehber olmadaki önemli etkisi olabilir. Oysa tanılanma ya da eğitim hizmetlerinin planlanmasına yönelik çocuklarla yapılacak çalışmalar, okul öncesi dönemin önemini gösterecek ve çocukların görünürlüğüne dikkat çekecektir. Benzer şekilde, bu konuyla ilgili bütün paydaşlarla (öğretmen adayları, aileler, kanun yapıcılar, vb.) çalışmalar yürütülmesi gerekmektedir.

Son bulgu ise her ne kadar sayısal olarak üç büyük şehirde yapılan çalışmalara kıyasla diğer şehirlerde yapılan çalışmalar çok görünse de ülkemizdeki il sayısı bağlamında değerlendirildiğinde oranın düşük olduğu görülmektedir. Bunun altında yatan çeşitli sebepler olabilir. Bu sebeplerden biri üstün yetenekliler alanında uzmanlaşmış öğretim elemanlarının çoğunlukla hem vakıf hem de devlet üniversitelerinin yoğunlukta olduğu bu üç büyükşehirde görev yapıyor olması olabilir. Diğer bir sebep, her ne kadar üniversitelerde özel yetenekliler ya da üstün yetenekliler anabilim dalları, özel eğitim bölümlerine bağlı olarak açılmış olsa da bu anabilim dallarında, özel eğitim alanında uzmanlaşmış öğretim elemanlarının yeterli sayıda olmaması olabilir.

\section{Öneriler}

Bulgular birlikte değerlendirildiğinde aşağıdaki öneriler sunulabilir:

- Okul öncesi dönem üstün yetenekli çocuklarla ilgili çalışmalar ilgili alan uzmanlarıyla birlikte farklı disiplinlerde, yüksek lisans/doktora düzeyinde ya da projeler perspektifinde çalışılabilir. Bu alanda sunulacak proje önerileri öncelikli olarak değerlendirilebilir. Disiplinler arası bir araştırma yaklaşımıyla birlikte, araştırma ekibinde üstün/özel yeteneklilik uzmanı, okul öncesi dönem çocuğunu tanıyan bir çocuk gelişimi uzmanı, okul öncesi eğitim konusunda uzman okul öncesi eğitimcisi, bir psikolog gibi farklı disiplinlerden araştırmacıların yer aldığı projelerle kapsamlı araştırmalar yapılabilir.

- Örneklem ya da katılımcılarda farklı gruplarla çalışılabilir. Örneğin, çocukların kendilerinin katıldıkları çalışmalar planlanabilir. Ya da ebeveynler veya geniş ailelerin konuya ilişkin bakış açılarına odaklanan araştırmalar yapılabilir. Ebeveynler ve aile bireylerine yönelik farklı araştırma desenleri ve farklı araştırma sorularıyla planlanan çalışmalarla hem farkındalığın artırılması hem de gelişim hedeflenebilir. Okul öncesi dönem üstün yeteneklilerle ilgili çalışmalarda önemli bir paydaş olan, okul idarecilerinin bilgi, algı, farkındalık veya görüşlerini inceleyen araștırmalar yürütülebilir. Okul öncesi öğretmenlerinin bilgi ve farkındalıklarının artırılmasını sağlayan, onları üstün yeteneklilik konusunda güçlendiren çalışmalar yapılabilir. Okul öncesi öğretmen adaylarına yönelik hizmet öncesi aldıkları derslere bütünleştirme çalışmaları entegre edilebilir, 
dersler kapsamında gözlem çalışmalarına yer verilebilir, öğretmenlik uygulaması derslerinde bu konular üzerinde durulabilir ve teorik bilgi uygulamalarla desteklenebilir.

- Okul öncesi dönem üstün yetenekli çocuklara ilişkin akademik çalışmaların farklı bilimsel araştırma yöntemlerinin kullanılması bağlamında zenginleştirilmesi önerilebilir. Kültürün üstün yetenekli çocuklar üzerindeki etkisi, bütünleştirme kültüründe üstün yetenekli çocuğun yeri ya da üstün yetenekli çocukların geliştirdiği kültür bağlamını inceleyen etnografik çalışmalar planlanabilir. Toplumsal cinsiyet ya da bütünleştirme gibi konuların araştırılabileceği feminist çalışmalar yapılabilir. Okul öncesi dönem üstün yetenekli çocukların deneyimlerine odaklanan fenomenoloji çalışmaları uygulanabilir. Gerek öğretmenler gerek öğretmen adayları gerek aileler gerekse okul idareleriyle değişimi amaçlayan eylem araştırmaları gibi bilimsel çalışmalar geliştirilebilir. Nicel araştırma deseninin farklı yöntemleri de kullanılabilir.

- Ulusal bağlamı ele alan çalışmalar artırılabilir. Bununla birlikte, uluslararası çalışmaların incelendiği ya da Türkiye'de yürütülmüş olup uluslararası kaynaklarda yayımlanmış araştırmaların derlendiği meta analiz, meta sentez ve betimsel alanyazın çalışmaları okul öncesi dönem üstün yetenekli çocuklarla ilgili küresel bir perspektif sunmada etkili olabilir.

- Yasa, yönetmelik ve yönergelerin uygulamaya yansımasının değerlendirildiği çalışmalar yürütülebilir.

\section{Kaynakça}

Akar, İ. (2019). Öğretmen adaylarının özel yetenekli öğrenciyi aday gösterme tercihlerini etkileyen faktörler. YYÜ Eğitim Fakültesi Dergisi, 16(1), 1729-1758. http://dx.doi.org/10.23891/efdyyu.2019.178

Ata, S., Duran, Ç. \& Metin, E. N. (2020). Öğretmen adaylarının üstün yetenekli çocukların eğitimine yönelik tutumlarının belirlenmesi (Ağrı ili örneği). H.Ü. Sağlık Bilimleri Fakültesi Dergisi, 7(2), 159-171. http://dx.doi.org/Doi: 10.21020/husbfd.568228

Ataman, A. (2003). Üstün zekalı ve yetenekli çocuklar. A. Ataman (Ed.). Özel gereksinimli çocuklar ve özel eğitime giriş içinde (s. 175-197). Gündüz Eğitim ve Yayıncllık.

Bapoğlu Dümenci, S., Gürsoy, F. \& Aral, N. (2016, Eylül). Türkiye'de okul öncesi dönemdeki üstün potansiyalli ve üstün zekâlı olan çocukların eğitimleri. Kastamonu Eğitim Dergisi, 24(5), 2469-2480.

Bear, G. G., Slaughter, J. C., Mantz, L. S., \& Farley-Ripple, E. (2017). Rewards, praise, and punitive consequences: Relations with intrinsic and extrinsic motivation. Teaching and Teacher Education, 65, 10-20. https://doi.org/10.1016/i.tate.2017.03.001

Bethell, C., Jones, J., Gombojav, N., Linkenbach, J. \& Sege, R. (2019). Positive childhood experiences and adult mental and relational health in a statewide sample: Associations across adverse childhood experiences levels. JAMA Pediatric, 173(11), 1 11. http://dx.doi.org/Doi:10.1001/jamapediatrics.2019.3007

Bıçakçı, M. \& Baloğlu, M. (2018). Türkiye'de özel yeteneklilerle yapılan araştırmalarda yaratıcılık. İnönü Üniversitesi Eğitim Fakültesi Dergisi, 19(3), 327-343. http://dx.doi.org/10.17679/inuefd.481895

Bildiren, A. (2018). Okul öncesi dönemde bilişsel yetenek ile problem çözme becerilerinin arasındaki ilişkinin incelenmesi. Millî Eğitim, Özel Sayı/2018(1), 291-308. 
Bildiren, A. \& Bıkmaz Bilgen, Ö. (2019). Okul öncesi dönem üstün yetenekli çocuklar için aday bildirim ölçeği: Geçerlik ve güvenirlik çalışması. Ankara Üniversitesi Ĕgitim Bilimleri Fakültesi Özel Eğitim Dergisi, 20(2), 269-285.

http://dx.doi.org/10.21565/ozelegitimdergisi.475278

Bildiren, A., Gür, G., Sağkal, A. S. \& Özdemir, Y. (2020). Okul öncesi öğretmenlerinin üstün yetenekli çocukların tanılanması ve eğitimlerine ilişkin algıları. Ankara Üniversitesi Eğitim Bilimleri Fakültesi Özel Eğitim Dergisi, 21(2), 329-356. http://dx.doi.org/10.21565/ozelegitimdergisi.572326

Bildiren, A. \& Kargın, T. (2019). Proje temelli yaklaşıma dayalı erken müdahale programının üstün yetenekli çocukların problem çözme becerisine etkisi. Eğitim ve Bilim, 44(198), 343-360. http://dx.doi.org/10.15390/EB.2019.7360

Çalık, M. \& Sözbilir, M. (2014). Parameters of content analysis. Education and Science, 39(174), 33-38. http://dx.doi.org/10.15390/EB.2014.3412

Çitil, M. (2018). Türkiye'de üstün yeteneklilerin eğitimi politikalarının değerlendirilmesi. Millî Ĕ̆itim, Özel Sayı/2018, 143-172.

Çocuk Çalışma Grubu Raporu. (2018). On birinci kalkınma planı (2019-2023) (Yayın No: KB: 3022-ÖÍK: 803). T.C. Kalkınma Bakanlığı, Çocuk ve Gençlik Özel İhtisas Komisyonu.

Dağlığlu, H. E. (2014). Üstün yetenekli çocuklar. E. N. Metin \& A. İ. Yükselen (Ed.). Her yönüyle okul öncesi eğitim 1: Özel gereksinimli çocuklar ve kaynaştırma içinde (s. 481496). Hedef CS.

Dağlığlu, H. E., Turupcu Doğan, A. \& Basit, O. (2017). Kapsayıcı okul öncesi eğitim ortamlarında öğretmenler çocukların bireysel yeteneklerini belirlemek ve geliştirmek için neler yapıyor? GEFAD, 37(3), 883 - 910.

Daştan, Ș. (2016). Okul öncesi öğretmenlerinin öz-yeterlik düzeyleri ile üstün yeteneklilerin eğitimine yönelik tutumlarının karşılaştırılması (Yayım No. 451836) [Yüksek Lisans Tezi, Gazi Üniversitesi, Eğitim Bilimleri Enstitüsü]. Ulusal Tez Merkezi.

Diamond, A. (2012). Activities and programs that improve children's executive functions. Current Directions in Psychological Science, 21(5), 335-341.

https://doi.org/10.1177/0963721412453722

Diken, İ. H., Rakap, S., Diken, Ö., Tomris, G. \& Çelik, S. (2016). Early childhood inclusion in Turkey. Infants \& Young Children, 29(3), 231-238.

http://dx.doi.org/10.1097/IYC.0000000000000065

Duckworth, A. \& Gross, J. J. (2014). Self-control and grit: Related but separable determinants of success. Current Directions in Psychological Science, 23(5), 319-325. https://doi.org/10.1177/0963721414541462

Duran, A. \& Dağlığlu, H. E. (2017). Okul öncesi öğretmen adaylarının üstün yetenekli çocuklara ilişkin metaforik algıları. GEFAD, 37(3), 855-881.

Eisenberg, N., Valiente, C., Spinrad, T. L., Cumberland, A., Liew, J., Reiser, M., Zhou, Q. \& Losoya, S. H. (2009). Longitudinal relations of children's effortful control, impulsivity, and negative emotionality to their externalizing, internalizing, and co-occurring behavior problems. Developmental Psychology, 45(4), 988-1008.

https://doi.org/10.1037/a0016213 
Elo, S. \& Kynga“s, H. (2007). The qualitative content analysis process. Journal of Advanced Nursing 62(1), 107-115. http://dx.doi.org/10.1111/j.1365-2648.2007.04569.x

Gagne, F. (2013). The DMGT 2.0: From gifted inputs to talented outputs. In C. M. Callahan \& H. L. Hertberg-Davis (Eds.). Fundamentals of gifted education: Considering multiple perspectives (s. 56-69). Routledge.

Gallagher, J. J. (2008). Psychology, psychologists, and gifted students. In S. I. Pfeiffer (Ed.), Handbook of giftedness in children: Psychoeducational theory, research, and best practices (s. 1-13). Springer.

Gökdemir, S. (2017). Ülkemizde özel yetenekli öğrencilerin tanılama sürecinin öğretmen veli ve öğrenci görüşlerine göre değerlendirilmesi (Yayım No. 481276) [Yüksek Lisans Tezi, Necmettin Erbakan Üniversitesi, Eğitim Bilimleri Enstitüsü]. Ulusal Tez Merkezi.

Gürkan, T. (2009). Erken çocukluk dönemi ve okul öncesi eğitim. Anadolu Üniversitesi, AÖF Yayın No:957.

Heller, K. A. (2004). Identification of gifted and talented students. Psychology Science, 46(3), 302 - 323.

İlik, S. S. (2019, Ocak). Üstün yetenekli öğrencilerin eğitiminde görev yapan öğretmenlerin bireyselleștirilmiş eğitim programları hazırlamaya uygulamaya ve izlemeye yönelik görüşlerinin değerlendirilmesi. Kastamonu Eğitim Dergisi, 27(2), 485-495. http://dx.doi.org/10.24106/kefdergi.2569

Kağıtçıbaşı, Ç. (2012). Benlik, aile ve insan gelişimi: Kültürel psikoloji. Koç Üniversitesi Yayınları.

Karadağ, F. \& Yıldız Demirtaş, V. (2017, Ağustos). Okul öncesi dönem ve özel yetenek. Uluslararası Sosyal Araştırmalar Dergisi, 10(51), 737-745. http://dx.doi.org/10.17719/jisr.2017.1810

Karateke, B. (2016). Üstün yetenek potansiyeli olan çocuklara uygulanan sosyal beceri eğitim programının sosyal beceri gelişimine etkisinin incelenmesi (Yayım No. 429538) [Doktora Tezi, Gazi Üniversitesi, Eğitim Bilimleri Enstitüsü]. Ulusal Tez Merkezi.

Karateke, B. (2019). Okul öncesi dönemde özel yeteneğin değerlendirilmesinde nöropsikolojik bir yaklaşım: Renkli progresif matrisler testi güvenirlik ve geçerlik çalışması. Çocuk ve Gelişim Dergisi, 2(4), 12-25.

Kıral, B. (2020). Nitel bir veri analizi yöntemi olarak doküman analizi. Siirt Üniversitesi Sosyal Bilimler Enstitüsü Dergisi, 8(15), 170-189.

Koç, F. \& Saranlı, A. G. (2017). Erken çocukluk dönemindeki üstün yetenekli çocuklara ilişkin Türkiye'deki lisansüstü çalışmaların çok boyutlu analizi. Mehmet Akif Ersoy Üniversitesi Eğitim Fakültesi Dergisi, 41, 163-183. http://dx.doi.org/ 10.21764/efd.81302

Majid, R. A. \& Alias, A. (2010). Consequences of risk factors in the development of gifted children. International Conference on Learner Diversity 2010: Procedia - Social and Behavioral Sciences, 7, 63-69. http://dx.doi.org/doi:10.1016/i.sbspro.2010.10.010

Mischel, W. (2014). The Marshmallow Test: Mastering self-control. Little, Brown and Company. 
Metin, N., Şenol, F. B. \& İnce, E. (2017). Determination of the prospective teachers' attitudes toward the education of the gifted children. Kuramsal Eğitimbilim Dergisi, 10(1), 95-116. http://dx.doi.org/10.5578/keg.27591

Milli Eğitim Bakanlığı. (2020, Ekim). Bilim ve sanat merkezleri güçleniyor. Milli Eğitim Bakanlığı.http://meb.gov.tr/bilim-ve-sanat-merkezleri-gucleniyor/haber/21827/tr

Mindivanlı Akdoğan, E., Koçak, G. \& Subaşı, M. (2017, Güz). Özel yetenekli çocukların belirlenmesinde okul öncesi öğretmenlerinin görüşleri. Eğitim ve İnsani Bilimler Dergisi, 8(16), 1-22.

Orhan-Karsak, H. G. \& Gider, B. (2019). Metaphorical perceptions and views of teachers about gifted and talented students and their education. Cumhuriyet International Journal of Education, 8(4), 961-982. http://dx.doi.org/10.30703/cije.543321

Ormrod, J. E. (2012). Human Learning (6. Bs.). Allyn \& Bacon.

Özcan, D. \& Gülkaya, Ş. (2019). Okul öncesi öğretmenlerinin üstün yetenekli çocuklara yönelik algı ve eğitim ihtiyaçlarının belirlenmesi. Kastamonu Eğitim Dergisi, 27(5), 2355-2368. http://dx.doi.org/Doi: 10.24106/kefdergi.3776

Özdemir, D. (2019). Üstün yetenekli okul öncesi çocuklarında sayı algısı kavramı. Bilim, Eğitim, Sanat ve Teknoloji Dergisi (BEST Dergi), 3(2), 69-77.

Özel Eğitim ve Rehberlik Hizmetleri Genel Müdürlüğü (2016, Kasım). Bilim ve sanat merkezleri yönergesi. Tebliğler Dergisi, 79(2710), 449-473. https://orgm.meb.gov.tr/meb iys dosyalar/2017 01/02031535 tebligler dergisi.p $\underline{\mathrm{df}}$

Özel Eğitim ve Rehberlik Hizmetleri Genel Müdürlüğü (2019, Aralık). Bilim ve sanat merkezleri yönergesi. Tebliğler Dergisi, 82(2747), 390-434. https://www.memurlar.net/common/news/documents/872519/2747_aralik_201 9.pdf

Saranll, A. G. (2017). Eş zamanlı olmayan gelişimin üstün yetenekli çocuklardaki görünümü üzerine bir örnek olay çalışması. Ankara Üniversitesi Eğitim Bilimleri Fakültesi Özel Eğitim Dergisi, 18(1), 89-108.

http://dx.doi.org/10.21565/ozelegitimdergisi.300060

Saranlı, A. G., Er, S. \& Deniz, K. Z. (2017). Okul öncesi dönemdeki üstün yetenekli çocukların dil gelişimlerinin analizi. Yaşadıkça Eğitim, 31(1), 1-20.

Sarar, M. (2018). Okul öncesi öğretmenlerinin üstün yetenekliler eğitimine ilişkin öz yeterlik düzeyleri ile üstün yeteneklilerin eğitimine yönelik algı ve bilgisi arasındaki ilişkinin incelenmesi (Yayım No. 513004) [Yüksek Lisans Tezi, İstanbul Aydın Üniversitesi, Sosyal Bilimleri Enstitüsü]. Ulusal Tez Merkezi.

Shonkoff, J. P. \& Phillips, D. A. (Ed.). (2000). From neurons to neighborhoods: The science of early childhood development. National Academies Press. http://dx.doi.org/10.17226/9824

Suğur, N. \& Doğru, E. S. (2010). Koruma altındaki çocukların aile ve devlet algısı üzerine bir araştırma. Ankara Üniversitesi SBF Dergisi, 65(1), 115-133.

Woodhead, M. (2005). Chapter 3: Psychology and the cultural construction of children's needs. In James, A. \& Prout, A. (Ed.) Constructing and reconstructing childhood: Contemporary issues in the sociological study of childhood (2. Ed.)(s. 61-81). Falmer. 
Yazıcı, D., Akman, B., Mercan-Uzun, E. \& Kardeș, S. (2017). Preservice preschool teachers' views on the characteristics of gifted children. Journal for the Education of Gifted Young Scientists, 5(3), 70-89. http://dx.doi.org/10.17478/JEGYS.2017.65

Yllmaz, E. (2018). Erken çocukluk döneminde üstün yetenekliler ile ilgili Türkiye'de yapılan çalışmaların incelenmesi. Uluslararası Erken Çocukluk Eğitimi Çalışmaları Dergisi, 3(1), 1-16.

Yörük, S. (2020). Okul öncesi dönemde özel yetenekli bir çocuk yetiştirmek. Çocuk ve Medeniyet, 5(10), 337-364. http://dx.doi.org/10.47646/CMD.2020.213

Yuvacı, Z. \& Dağlığlu, H. E. (2016). Okul öncesi dönem üstün yetenekli çocukların yaratıcllıklarını desteklemede öğretmene düșen görevler ve etkinlik örnekleri. International Journal of Early Childhood Special Education (INT-JECSE), 8(1), 39-61. http://dx.doi.org/Doi: 10.20489/intjecse.239575

Yoleri, S., Tetik, G. \& Çetken, H. Ş. (2018). Okul öncesi öğretmenlerinin üstün yetenekli çocuklar hakkındaki görüşlerinin belirlenmesi (Uşak ili örneği). GEFAD / GUJGEF, 38(1), 159-183.

\section{Extended Summary}

\section{Preschool Age Gifted/Talented Children: Where Are We? Where Should We Go?}

\section{Introduction}

Early childhood period includes an age of 0-8 in international context. In Turkey, it refers to ages between 0-6 and is called as pre-school period (Gürkan, 2009; Kağıtçıbaşı, 2012). Brain studies revealed the determinant role of experience and relationships in early childhood, contrary to previous belief. Those studies revealed that experiences and relationships have irreversible effects on children's lives. In other words, they leave permanent marks especially in the preschool period with physical, social, emotional, and cultural environment (Shonkoff and Phillips, 2000). The important point emphasized by both brain research and early childhood studies is that the support provided from an early age has a strong start in life. From the beginning of 2016 to the end of 2020, revealing the five-year studies on gifted/talented children in pre-school period will play an important role in seeing where we are and planning future studies. It is thought that this study will have a significant impact on the realization of the goals of quality education (goal 4) and reducing inequalities (goal 10) among the 2030 goals of the United Nations Development Program. In this context, the purpose of this study was to analyze article and master / doctorate thesis studies conducted for pre-school gifted/talented children between 20162020 in Turkey.

\section{Method}

Current study is a descriptive literature review. The sample included studies concerning preschool age gifted/talented children in Turkey published between 2016 and 2020. The established keywords were "'üstün yetenek (giftedness/talented)" and "okul öncesi 
(preschool)"; and both keywords were scanned in Turkish. Articles about the aim were reached via Ulakbim; and master's / doctoral thesis were reached through the Turkish National Thesis Center. Thus, the sample was consisted of three master's and one doctoral thesis, and 20 articles. Content analysis techniques was implemented. Through data analysis, two categories as article and master / doctorate thesis; three sub-categories as research type, research group and the place where research was conducted; codes of research method as qualitative research design, quantitative research design, mixed design and literature review; and codes of research groups as research with children, research with teachers and research with teacher candidates were formed. For validity and reliability, coder compatibility was checked with an expert who has a bachelor's degree in preschool education and works as a preschool teacher. In this study in which 25 studies were analyzed, disagreement was observed in three of the 63 items coded. Three disagreements were resolved with the opinion of an expert researcher in the field. Accordingly, one article was excluded from the analysis, 20 articles and four theses were evaluated. Inter-coder agreement was 95,2\%.

\section{Results}

When articles between 2016 and 2020 were examined, it was found that three of the 20 articles (15\%) were literature reviews and the remaining 17 (85\%) were research articles. It was found that two of the literature review studies focused on the concepts of creativity and giftedness, and one examined the theses made on gifted/talented preschool children. It was striking that creativity and gifted/talented preschool children topic was handled in only literature review studies, and no research publication was reached on this subject.

The majority of research articles were conducted by using qualitative research design (40\%), 40\% quantitative research design and only one (5\%) mixed design. Three of them $(15 \%)$ were literature reviews. When thesis studies on gifted/talented preschool children were examined between specified dates, it was found that three of four thesis studies $(75 \%)$ were master's and one (25\%) was doctoral study; three $(75 \%)$ including doctoral dissertation used quantitative research design and only one $(25 \%)$ used qualitative design; and no study using mixed design were determined.

Data analysis according to research group sub-theme showed that five of the 17 research articles were conducted with children (24\%), eight with teachers (47\%) and four with prospective teachers (24\%). Three of the five studies with children were conducted in quantitative, one qualitative and one with mixed design. Only one of the quantitative studies conducted with children was experimental. One scale development study conducted with gifted/talented children in preschool period and the other was carried out with teachers. In addition, it was observed that one of the quantitative studies focused on language development in pre-school gifted/talented children. Six of the eight article studies conducted with teachers were planned with qualitative research and the remaining two were planned with a quantitative research design, while three of the studies conducted with pre-service teachers used quantitative and one used a qualitative design. When data analysis was conducted in context of theses, it was observed that only one doctoral dissertation was worked with children, while the other three master's theses worked with teachers.

When articles were analyzed according to the place where study was conducted subtheme, it was seen that all the studies children participated, were carried out in one of the three metropolitan cities. Results of data analysis belonging to studies that teachers were the participants showed following situation about location information: no information 
was reached in one study; one was conducted in one of the three metropolitan cities; international participants were participated to one study; one was conducted in Eastern Anatolia region; one was conducted in the TRNC; and the others were applied in the Central Anatolia and Aegean regions. For studies conducted with teacher candidates, there was no clear information about the place of two studies; one study was carried out in one of the three metropolitan cities; and the other study was conducted in a province in Eastern Anatolia. When thesis studies were examined accordingly, it was determined that two of them were applied in one of the three metropolitan cities of Turkey, one in a metropolitan in Central Anatolia and the other in the whole country.

\section{Discussion}

When results were evaluated in general, it was seen that there were six studies conducted with gifted/talented children in pre-school period; on the contrary, it was seen that 11 out of 21 research studies (article and thesis together) conducted on this subject were conducted with teachers, and four of them were conducted with pre-service teachers. In last five years, in theses and articles published in Turkey, no study was reached to be conducted with families, administrators or other stakeholders under the protection of the state. However, issues such as the importance of the family's approach to the gifted/talented child in terms of education and the regulation of the home environment; the authority of the administrators to regulate the current environment within the legal framework, the recognition of gifted/talented children under the protection of the state and the necessity of making the necessary regulations were in the $11^{\text {th }}$ Development Plan of Turkey (Child Working Group Report, 2018). It was also underlined in the 2019-2023 development goals.

After evaluating findings together, it can be suggested to enrich academic studies on gifted/talented children in preschool period in context of diversity. This enrichment might be such: from studies in which the child's voice is heard to studies focusing on the perspective of parents or extended families on the subject, from the knowledge, perception, awareness or opinions of school administrators to studies on empowering preschool teachers. For example, ethnographic studies examining the impact of culture on gifted/talented children, the place of gifted/talented children in the culture of integration, or the cultural context developed by gifted/talented children can be planned; feminist studies where topics such as gender or integration can be explored; phenomenology studies focusing on the experiences of gifted/talented children in preschool period or action research aiming change can be developed. Likewise, studies that empower preschool teachers' roles in inclusion of gifted/talented children and increase their knowledge and awareness can be planned. Studies for parents and family members can be planned by different research designs and researching different research questions, and thus, raising awareness and development can also be targeted. For preservice teachers, inclusion studies can be integrated into courses; observation studies can be included in those courses; these issues can be emphasized in teaching practice courses; and theoretical knowledge can be supported with practicum. Literature reviews of international studies or of studies carried out in Turkey and published internationally can be effective in providing a global perspective on preschool age gifted/talented child. 


\section{Yazar(lar)ın Beyanı}

Araştırmacıların katkı oranı beyanı: Araştırmacılar çalışmaya eşit oranda katkı yapmışlardır.

Etik Kurul Kararı: Bu makalede sunulan çalışmanın bir derleme çalışması olması nedeniyle etik kurul iznine gerek duyulmamaktadır.

Çatışma beyanı: Araştırmada yazarlar arasında ya da diğer kişi/kurum/kuruluşlarla herhangi bir çıkar çatışması bulunmamaktadır.

Destek ve teşekkür: $\mathrm{Bu}$ araştırma için herhangi bir kurumdan finansal destek alınmamıştır. 